Article

\title{
An Experimental Study on the Melting Solidification of Municipal Solid Waste Incineration Fly Ash
}

\author{
Jing Gao ${ }^{1}$, Tao Wang ${ }^{2}$, Jie Zhao ${ }^{3}$, Xiaoying $\mathrm{Hu}^{1, *}$ and Changqing Dong ${ }^{1,4}$ \\ 1 National Engineering Laboratory for Biomass Power Generation Equipment, School of New Energy, \\ North China Electric Power University, Beijing 102206, China; jinggao@ncepu.edu.cn (J.G.); \\ dongcq@ncepu.edu.cn (C.D.) \\ 2 Solid Waste Project Department, Beijing Aerospace Petrochemical Technology EC and EP \\ Corporation Limited, Beijing 100010, China; wangt@calt11.cn \\ 3 School of Energy, Power and Mechanical Engineering, North China Electric Power University, \\ Beijing 102206, China; zjwork@ncepu.edu.cn \\ 4 State Key Laboratory of Alternate Electrical Power System with Renewable Energy Sources, \\ North China Electric Power University, Beijing 102206, China \\ * Correspondence: huxy@ncepu.edu.cn
}

check for updates

Citation: Gao, J.; Wang, T.; Zhao, J.; $\mathrm{Hu}, \mathrm{X}$.; Dong, C. An Experimental Study on the Melting Solidification of Municipal Solid Waste Incineration Fly Ash. Sustainability 2021, 13, 535. https://doi.org/10.3390/su13020535

Received: 1 December 2020

Accepted: 5 January 2021

Published: 8 January 2021

Publisher's Note: MDPI stays neutral with regard to jurisdictional clai$\mathrm{ms}$ in published maps and institutional affiliations.

Copyright: $(\odot 2021$ by the authors. Licensee MDPI, Basel, Switzerland. This article is an open access article distributed under the terms and conditions of the Creative Commons Attribution (CC BY) license (https:// creativecommons.org/licenses/by/ $4.0 /)$.

\begin{abstract}
Melting solidification experiments of municipal solid waste incineration (MSWI) fly ash were carried out in a high-temperature tube furnace device. An ash fusion temperature (AFT) test, atomic absorption spectroscopy (AAS), scanning electron microscope (SEM), and X-ray diffraction (XRD) were applied in order to gain insight into the ash fusibility, the transformation during the melting process, and the leaching behavior of heavy metals in slag. The results showed that oxide minerals transformed into gehlenite as temperature increased. When the temperature increased to $1300{ }^{\circ} \mathrm{C}, 89^{\circ} \mathrm{C}$ higher than the flow temperature (FT), all of the crystals transformed into molten slag. When the heating temperatures were higher than the FT, the volatilization of the $\mathrm{Pb}, \mathrm{Cd}, \mathrm{Zn}$, and $\mathrm{Cu}$ decreased, which may have been influenced by the formation of liquid slag. In addition, the formation of liquid slag at a high temperature also improved the stability of heavy metals in heated slag.
\end{abstract}

Keywords: municipal solid waste incineration; fly ash; melting solidification; minerals; heavy metals

\section{Introduction}

Municipal solid waste incineration (MSWI) fly ash is classified as hazardous waste [1], because it may contain polychlorinated dibenzo-p-dioxins and furans (PCDD/Fs), as well as heavy metals, such as lead, cadmium, chromium, mercury, and zinc. MSWI fly ash management includes separation processes, thermal methods (sintering, melting, and vitrification), and solidification/stabilization technology [2,3]. The melting solidification of fly ash has received attention, because it stabilizes heavy metals and simultaneously removes harmful organics, such as dioxins/furans [4]. Furthermore, the non-volatile heavy metals can be solidified in the dense lattice structure of glassy slag, which reduces the possibility of heavy metal dissolution and, thus, realizes the control of heavy metal [5]. Previous studies in Japan have shown that melting treatment is a promising thermal technology for MSWI fly ash [6].

The content and chemical speciation of heavy metals in MSWI fly ash are closely related to the composition of municipal solid waste. The sources of heavy metals in municipal solid waste are complex, such as $\mathrm{Cd}, \mathrm{Zn}$, and $\mathrm{Hg}$ in batteries, $\mathrm{Cd}$ in pigments and stabilizers in plastics, and $\mathrm{Cu}, \mathrm{Zn}$, and $\mathrm{Cr}$ in printing inks and paints. Abanades et al. [7] divided heavy metals into three main families, according to their volatility: $\mathrm{Cr}$ and $\mathrm{Ni}$, which were mainly found in bottom ash. $\mathrm{Pb}$ and $\mathrm{Zn}$ are partially volatilized. $\mathrm{Hg}$ and $\mathrm{Cd}$ highly volatilize during incineration. The volatile heavy metals, except $\mathrm{Hg}$, can adsorb on the surface of fly ash particles during flue gas cooling processes $[7,8]$. 
The volatilization of heavy metals from fly ash during the melting process, which can cause secondary pollution, has been widely observed. There are two treatment methods for heavy metals in fly ash: (1) the recovery of heavy metals by promoting the volatilization of heavy metals $[9,10]$ and (2) the solidification of heavy metals in sinter/glass slag by inhibiting the volatilization of heavy metals [11,12]. The migration of heavy metals is influenced by the composition of fly ash, reaction temperature, and atmosphere [13-15]. Chlorides $\left(\mathrm{CaCl}_{2}, \mathrm{KCl}, \mathrm{NaCl}\right)$ in fly ash, especially $\mathrm{CaCl}_{2}$, can promote the volatilization of heavy metals [16,17]. Most of the chlorides can be recovered by washing [18], thus inhibiting the volatilization of heavy metals during heat treatment [10]. In addition, $\mathrm{CaO}$ and $\mathrm{SiO}_{2}$ in fly ash can influence the migration of heavy metals by affecting the melting process at a high temperature $[11,19]$. The leaching behavior of heavy metals is an important indicator in environmental monitoring, and it is the basis of distinguishing treatment and disposal methods of MSWI fly ash.

Melting solidification experiments of this fly ash were carried out in a high temperature tube furnace device in order to provide a basis for the treatment method of MSWI fly ash. First, physicochemical properties, including the chemical composition, microstructure, and melting characteristics, of fly ash were investigated. Second, phase analysis and an investigation of the target heavy metal contents $(\mathrm{Pb}, \mathrm{Cd}, \mathrm{Zn}$, and $\mathrm{Cu}$ ) in raw fly ash and heated slag were conducted in order to explain the mineral transformation and the migration of heavy metals during the melting treatment process. Last, a characteristic toxicity leaching procedure was applied to evaluate the chemical stability of the heated slag.

\section{Method}

\subsection{Materials and Characterization}

The raw fly ash used in the experiment came from the bag filter of a municipal waste incineration plant (circulating fluidized bed boiler) in Shanxi Province. The flue gas desulphurization system consists of $\mathrm{CaCO}_{3}$ dosing equipment in a furnace and a semi-dry circulating fluidized bed flue gas purification tower. The chemical compositions of fly ash were characterized through X-ray fluorescence spectrometry (ARL ADVANT-XP). The mineral compositions of fly ash were analyzed while using X-ray diffraction (SHIMADZU XRD-6000). The scanning angle (2 Theta) was from $3^{\circ}$ to $70^{\circ}$ at a scanning speed of $6^{\circ} / \mathrm{min}$. The X-ray diffraction (XRD) pattern was analyzed while using the computer software package MDI Jade. A scanning electron microscope (SEM) (HITACHI S-4800) was used to observe the surface morphology of raw fly ash. The melting behavior of raw fly ash was detected using a high-temperature ash fusibility tester. The experiments were conducted according to the procedures that were outlined in the Chinese standard GB/T219-2008 [20]. The ash fusion temperatures (AFTs) were characterized based on the initial deformation temperature (IDT), softening temperature (ST), hemispheric temperature (HT), and flow temperature (FT).

\subsection{Experimental Devices and Methods}

Figure 1 depicts the fly ash melting system. It is composed of a gas system, a horizontal high-temperature corundum tube furnace, and a gas-cleaning device. The corundum crucible containing $10 \mathrm{~g}$ of dried fly ash was placed at the center of the tube when the furnace temperature reached the target temperature $\left(950^{\circ} \mathrm{C}, 1000^{\circ} \mathrm{C}, 1050{ }^{\circ} \mathrm{C}, 1100{ }^{\circ} \mathrm{C}\right.$, $1150^{\circ} \mathrm{C}, 1200^{\circ} \mathrm{C}, 1250^{\circ} \mathrm{C}$, and $1300^{\circ} \mathrm{C}$ ) with a $100 \mathrm{~mL} / \mathrm{min}$. air flow rate. After $30 \mathrm{~min}$., the crucible was taken out and cooled. The exhaust gas was purified by activated carbon before being discharged.

\subsection{Heavy Metal Concentration}

Atomic absorption spectroscopy (AAS) determined the target heavy metals content in the raw fly ash and heated slag after digestion by applying the $\mathrm{HCl}-\mathrm{HNO}_{3}-\mathrm{HF}-\mathrm{HClO}_{4}$ method according to the Chinese standard GB17141-1997 [21]. An amount of $0.1 \mathrm{~g}$ sample was tested in each experiment and each sample was tested twice. 


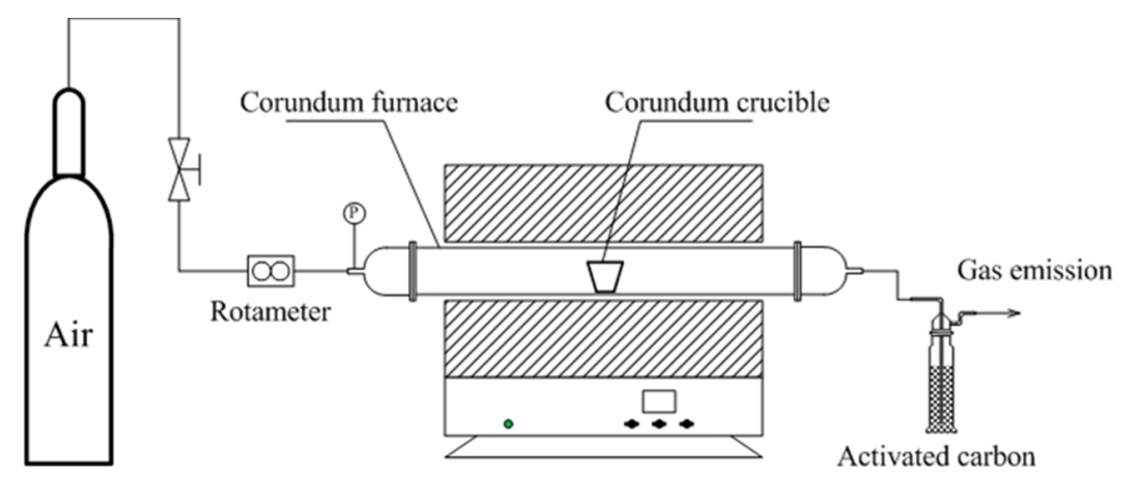

Figure 1. The fly ash melting system.

\subsection{Leaching Tests}

The leaching behavior of heavy metals from raw fly ash and heated slag was evaluated through a toxicity characteristic leaching procedure according to Chinese standard HJ/T 300-2007 [22]. Firstly, the extraction solution that was used in the experiment was determined. An amount of $96.5 \mathrm{~mL}$ of deionized water was added to $5.0 \mathrm{~g}$ of raw fly ash, and the mixture was magnetically stirred for $5 \mathrm{~min}$. at a high speed. The $\mathrm{pH}$ value was determined to be 10.67. Afterwards, $3.5 \mathrm{~mL}$ of $1 \mathrm{~mol} / \mathrm{L} \mathrm{HCl}$ was added to the solution, which was heated at $50{ }^{\circ} \mathrm{C}$ for $10 \mathrm{~min}$. and cooled to room temperature. The measured $\mathrm{pH}$ value of the solution was 5.78. This and previous measured $\mathrm{pH}$ values were greater than 5.0. Therefore, the acetic acid solution with a $\mathrm{pH}$ value of $2.64 \pm 0.05$ was selected as the extract solution. Afterwards, the sample was mixed with an acetic acid solution $(\mathrm{pH}=2.64 \pm 0.05)$ at a liquid-to-solid ratio of 20:1, and then flip oscillated for $(18 \pm 2 \mathrm{~h})$ at a speed of $30 \pm 2 \mathrm{r} / \mathrm{min}$. The leaching solution was then extracted through filtration while using a $0.8 \mu \mathrm{m}$ membrane filter. The concentrations of the target heavy metals were examined using AAS after digestion by applying the $\mathrm{HNO}_{3}-\mathrm{HClO}_{4}$ method according to the Chinese standard HJ787-2016 [23]. An amount of $2.5 \mathrm{~g}$ sample was tested in each experiment and each sample was tested twice.

\section{Results and Discussion}

\subsection{Characteristics of the MSWI Fly Ash}

$\mathrm{XRF}$ and AAS detected the compositions of the raw fly ash. Table 1 shows the main chemical compositions and heavy metal content. The main compositions of fly ash included $\mathrm{CaO}, \mathrm{SiO}_{2}, \mathrm{Al}_{2} \mathrm{O}_{3}$, chloride, and sulfur-containing compounds. The content of $\mathrm{Zn}, \mathrm{Cu}$, and $\mathrm{Pb}$ were high, while the content of $\mathrm{Cd}$ was relatively low.

Table 1. The main chemical compositions (XRF) and heavy metal content (atomic absorption spectroscopy (AAS)) of raw fly ash.

\begin{tabular}{|c|c|c|c|c|c|c|c|c|c|}
\hline Chemical compositions & $\mathrm{CaO}$ & $\mathrm{SiO}_{2}$ & $\mathrm{Al}_{2} \mathrm{O}_{3}$ & $\mathrm{Na}_{2} \mathrm{O}$ & $\mathrm{K}_{2} \mathrm{O}$ & $\mathrm{SO}_{3}$ & $\mathrm{Cl}$ & $\mathrm{Fe}_{2} \mathrm{O}_{3}$ & $\mathrm{MgO}$ \\
\hline Content (wt.\%) & 30.09 & 17.91 & 11.9 & 1.26 & 2.35 & 5.45 & 5.23 & 4.4 & 1.97 \\
\hline Heavy metal & \multicolumn{2}{|c|}{$\mathrm{Cd}$} & \multicolumn{2}{|c|}{$\mathrm{Pb}$} & \multicolumn{2}{|c|}{$\mathrm{Zn}$} & \multicolumn{3}{|c|}{$\mathrm{Cu}$} \\
\hline Content (mg/kg) & \multicolumn{2}{|c|}{60.9} & \multicolumn{2}{|c|}{677.4} & \multicolumn{2}{|c|}{1166.3} & \multicolumn{3}{|c|}{1070.2} \\
\hline
\end{tabular}

The surface morphology and specific surface area of fly ash particles affect the surface energy of the particles, which is the driving force of the sintering process. The finer the specific surface area, the higher the surface energy is, and the stronger the surface activity of fly ash particles [24,25]. The particle size of the MWSI fly ash is mainly concentrated in a range of 5-30 $\mu \mathrm{m}$. The morphologies of fly ash particles under SEM as shown in Figure 2 were varied: (a) the particles were spherical with clastic particles that were attached to the surface. (b) Irregularly shaped polymers formed from the accumulation of particles of 
various shapes, including spherical, flake, and block particles. (c) A bar polymer formed from the accumulation of rod and columnar particles with intergranular porosity. (d) A small number of rod-shaped particles were distributed in the fly ash. (e) There was a small amount regular blocks in the fly ash. The morphological characteristics under the SEM scanning of fly ash are consistent with the results of 60 groups of fly ash found in a study conducted by Guo et al. [26].
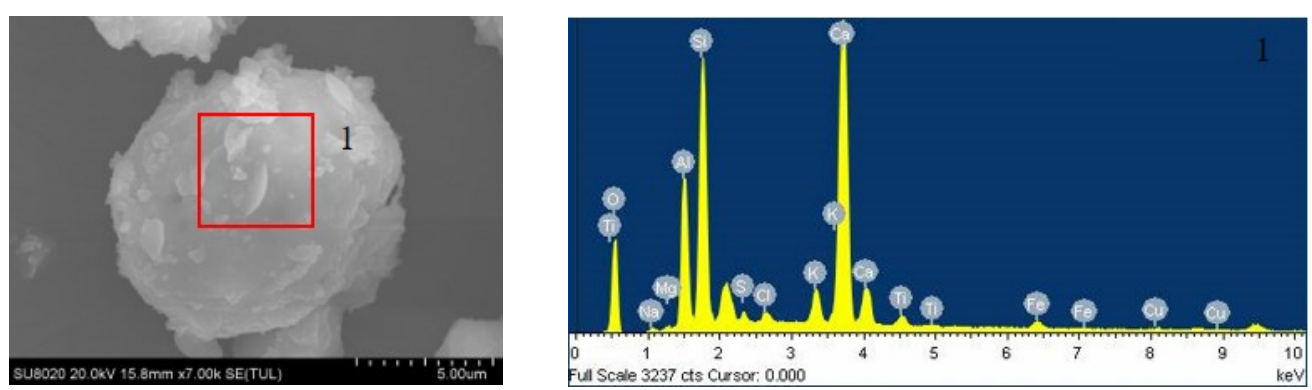

(a) Spherical particle.
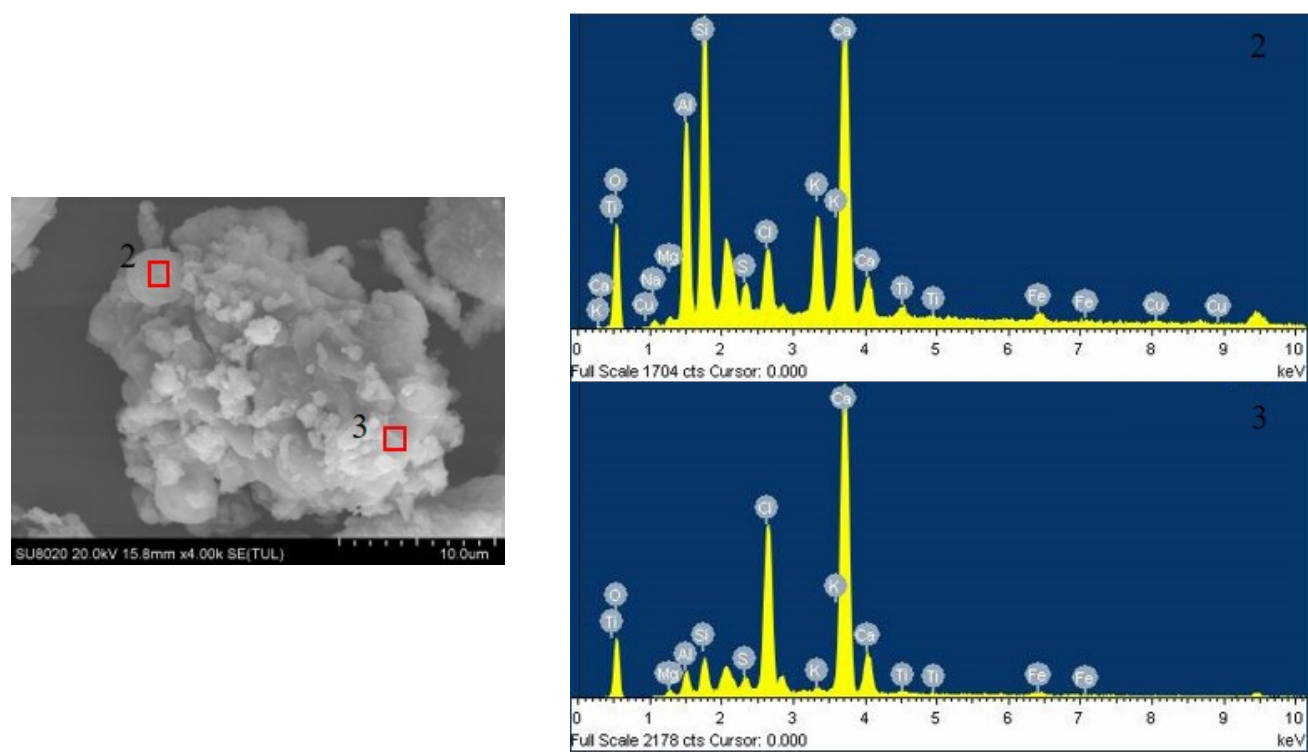

(b) Irregularly shaped polymer.
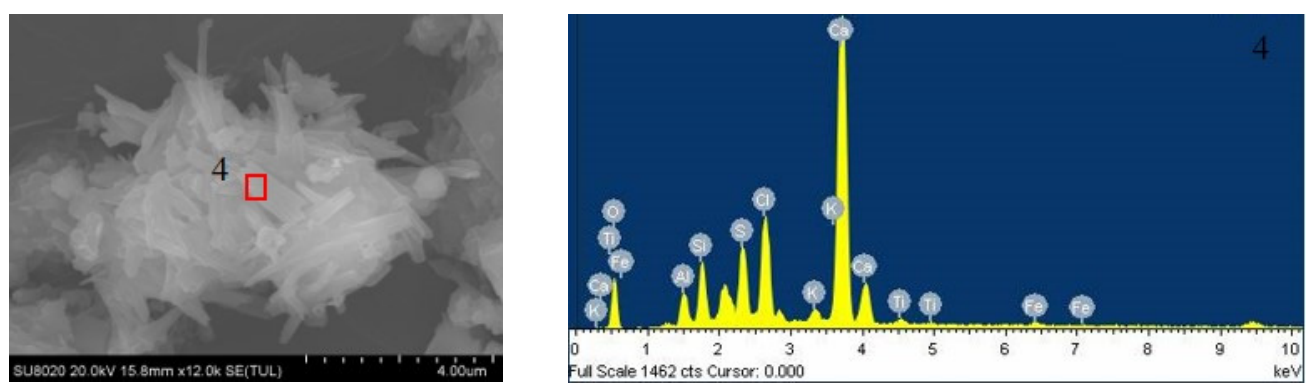

(c) Bar polymer.

Figure 2. Cont. 

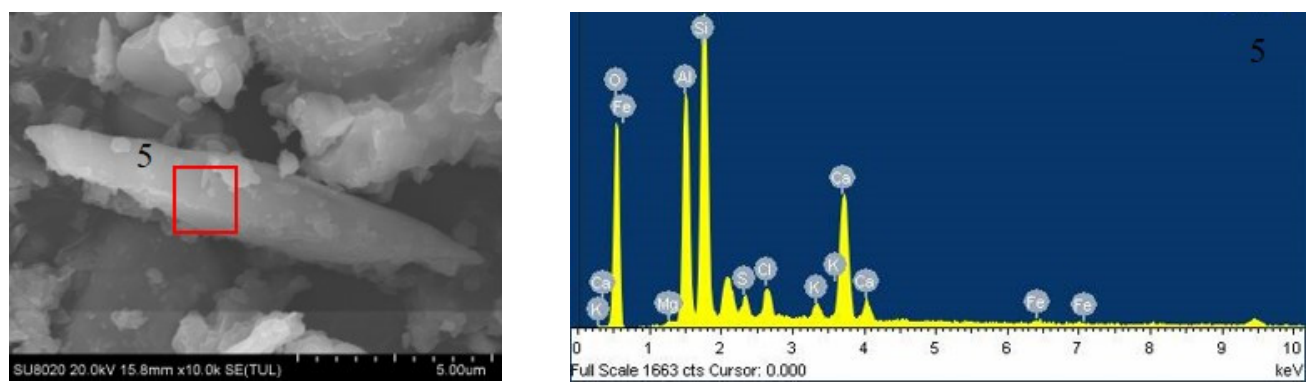

(d) Rod-shaped particle.
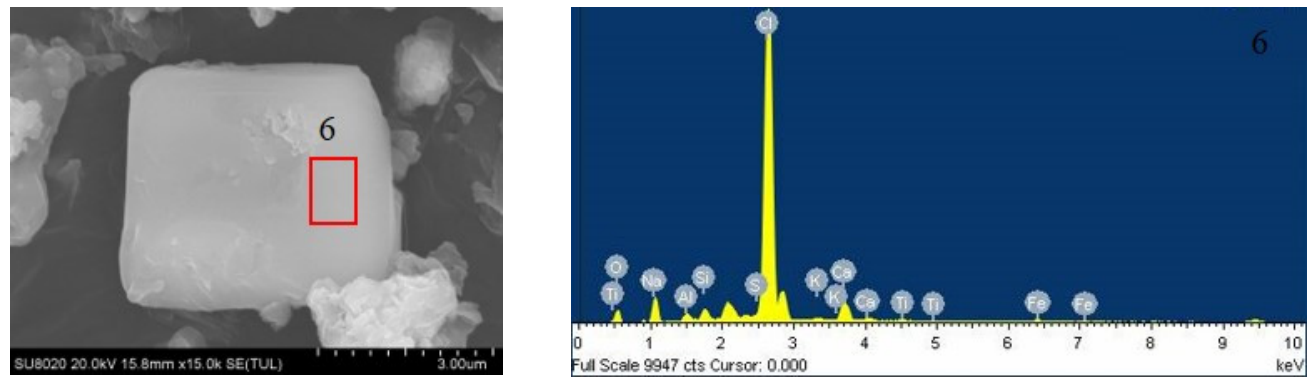

(e) Block.

Figure 2. SEM micrographs of fly ash particles: (a) Spherical particle; (b) Irregularly shaped polymer; (c) Bar polymer; (d) Rod-shaped particle; (e) Block.

Table 2 shows the elemental content of fly ash particles with different morphologies that were detected by EDS. Spherical and rod-shaped particles (Zones 1 and 5) were mainly composed of $\mathrm{Ca}, \mathrm{Si}, \mathrm{Al}$, and $\mathrm{O}$, and small amounts of $\mathrm{Cu}$ were attached to the spherical particles. Polymers (Zones 2, 3, and 4) also contained $\mathrm{Cl}$ and $\mathrm{S}$, in addition to $\mathrm{Ca}, \mathrm{Si}, \mathrm{Al}$, and $\mathrm{O}$. The block-shaped particle (Zone 6) was mainly composed of $\mathrm{Cl}, \mathrm{Na}, \mathrm{Ca}$, and $\mathrm{O}$. Few heavy metals were detected on the surface of the fly ash particles due to their low content. During the melting process, spherical particles, rod-shaped particles, and polymers formed a glass slag matrix, which can immobilize heavy metals.

Table 2. The elemental content of fly ash particles with different morphologies (EDS).

\begin{tabular}{ccccccc}
\hline \multirow{2}{*}{ Element } & Zone 1 & Zone 2 & Zone 3 & Zone 4 & Zone 5 & Zone 6 \\
\cline { 2 - 6 } & \multicolumn{7}{c}{ Weight (\%) } \\
\hline $\mathrm{O}$ & 41.75 & 38.67 & 42.41 & 37.12 & 53.33 & 20.17 \\
$\mathrm{Na}$ & 0.39 & 0.58 & 0 & 0 & 0 & 6.45 \\
$\mathrm{Mg}$ & 0.23 & 0.38 & 0.52 & 0 & 0.18 & 0 \\
$\mathrm{Al}$ & 8.13 & 8.79 & 1.53 & 2.25 & 11.42 & 1.17 \\
$\mathrm{Si}$ & 15.55 & 14.4 & 2.5 & 4.33 & 18.3 & 1.7 \\
$\mathrm{~S}$ & 0.79 & 1.92 & 1.01 & 6.1 & 1.63 & 0.61 \\
$\mathrm{Cl}$ & 0.76 & 3.94 & 14.6 & 9.82 & 2.28 & 62.17 \\
$\mathrm{~K}$ & 2.49 & 6.33 & 0.42 & 1.25 & 1.21 & 0.58 \\
$\mathrm{Ca}$ & 26.58 & 22.02 & 35.49 & 37.33 & 11.02 & 5.76 \\
$\mathrm{Ti}$ & 1.45 & 1.02 & 0.53 & 0.85 & 0 & 0.23 \\
$\mathrm{Fe}$ & 1.45 & 1.31 & 0.99 & 0.94 & 0.62 & 1.15 \\
$\mathrm{Cu}$ & 0.43 & 0.65 & 0 & 0 & 0 & 0 \\
\hline
\end{tabular}

Table 3 shows the ash fusion temperatures of MSWI fly ash. From $1167^{\circ} \mathrm{C}$ to $1211^{\circ} \mathrm{C}$, liquid slag affected the mass transfer rate of the heavy metals that formed [9]. The melting temperature also affects the energy consumption and equipment investment in the melting treatment process. 
Table 3. The ash fusion temperatures of municipal solid waste incineration (MSWI) fly ash.

\begin{tabular}{ccccc}
\hline AFTs $\left({ }^{\circ} \mathbf{C}\right)$ & IDT & ST & HT & FT \\
\hline FA & 1167 & 1180 & 1189 & 1211 \\
\hline
\end{tabular}

AFTs: Ash fusion temperatures; IDT: Initial deformation temperature; ST: Softening temperature; HT: hemispheric temperature; FT: flow temperature.

\subsection{Mineral Transformation Behavior}

The mineral transformation behavior of the fly ash during the melting process is complex. Figure 3 shows the phase characterizations of the raw fly ash and the heated slag at $950{ }^{\circ} \mathrm{C}, 1250{ }^{\circ} \mathrm{C}$, and $1300^{\circ} \mathrm{C}$ in order to obtain the mineral transformation behavior.

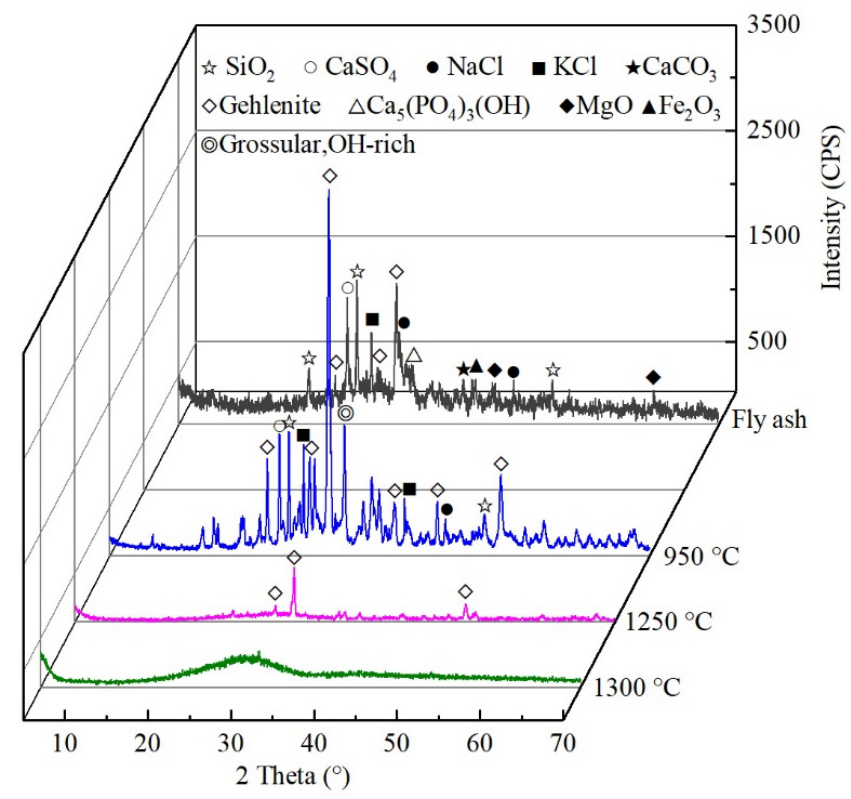

Figure 3. X-ray diffraction (XRD) patterns of raw fly ash and heated slag.

The raw fly ash mainly consists of nine minerals, including gehlenite $\left(\mathrm{Ca}_{2} \mathrm{Al}_{2} \mathrm{SiO}_{7}\right)$, quartz $\left(\mathrm{SiO}_{2}\right)$, anhydrite $\left(\mathrm{CaSO}_{4}\right)$, halite $(\mathrm{NaCl})$, sylvite $(\mathrm{KCl})$, periclase $(\mathrm{MgO})$, calcite $\left(\mathrm{CaCO}_{3}\right)$, hematite $\left(\mathrm{Fe}_{2} \mathrm{O}_{3}\right)$, and hydroxylapatite $\left(\mathrm{Ca}_{5}\left(\mathrm{PO}_{4}\right)_{3}(\mathrm{OH})\right)$, as shown in Figure 3 . In addition, the fly ash contains amorphous substances and the crystallinity determined using Jade software [27] was approximately $79 \%$. When the fly ash was heated at $950{ }^{\circ} \mathrm{C}$, a new, OH-rich mineral phase, grossular $\left(\mathrm{Ca}_{3} \mathrm{Al}_{2}\left(\mathrm{SiO}_{4}\right)_{2}(\mathrm{OH})_{4}\right)$ was formed. The crystallinity decreased to $67 \%$. At $1250{ }^{\circ} \mathrm{C}$, gehlenite became the main phase in the slag, which was due to the decomposition of $\mathrm{CaCO}_{3}$ and $\mathrm{CaSO}_{4}$ at high temperatures and the reactions with $\mathrm{Al}_{2} \mathrm{O}_{3}$ and $\mathrm{SiO}_{2}$. Moreover, there is no $\mathrm{NaCl}$ or $\mathrm{KCl}$ diffraction peak in the XRD pattern, whereas $\mathrm{Na}$ and $\mathrm{K}$ were detected in the slag, as shown in Table 4 . This may be due to the fact that $\mathrm{Na}$ and $\mathrm{K}$ were present in other forms. The possible transformation behavior for $\mathrm{NaCl}$ or $\mathrm{KCl}$ may be: (1) volatilization, (2) the reactions with $\mathrm{SiO}_{2} / \mathrm{Al}_{2} \mathrm{O}_{3} / \mathrm{PbO}$ [28-30], and $\mathrm{Na}$ and $\mathrm{K}$ would enter silicate matrix in the form of oxides. The crystallinity continued to decrease to $52 \%$. When the temperature increased to $1300{ }^{\circ} \mathrm{C}$, all of the crystals transformed into molten slag and formed a glassy slag after quenching.

Table 4. The main chemical compositions (XRF) of heated slag.

\begin{tabular}{|c|c|c|c|c|c|c|c|c|c|c|}
\hline \multicolumn{2}{|c|}{ Chemical Compositions (wt.\%) } & $\mathrm{CaO}$ & $\mathrm{SiO}_{2}$ & $\mathrm{Al}_{2} \mathrm{O}_{3}$ & $\mathrm{Na}_{2} \mathrm{O}$ & $\mathrm{K}_{2} \mathrm{O}$ & $\mathrm{SO}_{3}$ & $\mathrm{Cl}$ & $\mathrm{Fe}_{2} \mathrm{O}_{3}$ & $\mathrm{MgO}$ \\
\hline \multirow{3}{*}{$\begin{array}{c}\text { Heat } \\
\text { Temperature }\end{array}$} & $950^{\circ} \mathrm{C}$ & 28.29 & 27.8 & 19.53 & 2.63 & 1.99 & 1.73 & 5.75 & 4.13 & 3.56 \\
\hline & $1250^{\circ} \mathrm{C}$ & 28.82 & 34.57 & 21.41 & 1.62 & 0.679 & 0.503 & 1.65 & 3.07 & 3.54 \\
\hline & $1300^{\circ} \mathrm{C}$ & 28.44 & 34.35 & 21.42 & 1.53 & 0.62 & 0.426 & 1.45 & 4.1 & 3.53 \\
\hline
\end{tabular}




\subsection{Volatilization of Heavy Metals}

The fate of heavy metals during the melting process is expressed through volatilization fraction $R v$ [9], as shown in the following equation:

$$
R v=\left(1-\frac{c_{a} \times m_{a}}{c_{b} \times m_{b}}\right) \times 100 \%
$$

where $c_{a}$ is the concentration of heavy metal in the slag after treatment, $\mathrm{mg} / \mathrm{kg} ; m_{a}$ is the mass of the slag after treatment, $\mathrm{g} ; c_{b}$ is the concentration of heavy metal in the sample before treatment, $\mathrm{mg} / \mathrm{kg}$; and, $m_{b}$ is the mass of the sample before treatment, $\mathrm{g}$.

$\mathrm{Cd}$ and $\mathrm{Pb}$ volatilize more easily than $\mathrm{Zn}$ and $\mathrm{Cu}$, as shown in Figure 4 . The volatilization fractions of $\mathrm{Cd}$ and $\mathrm{Pb}$ at $950{ }^{\circ} \mathrm{C}$ were $48.5 \%$ and $75.7 \%$, respectively, and they increased rapidly to $92.0 \%$ and $95.8 \%$ at $1050{ }^{\circ} \mathrm{C}$, respectively. As the temperature increased, the volatilization of $\mathrm{Cd}$ and $\mathrm{Pb}$ slightly increased. When the temperature reached $1200{ }^{\circ} \mathrm{C}$ $(>\mathrm{HT})$, the volatilization of $\mathrm{Cd}$ and $\mathrm{Pb}$ decreased. $\mathrm{Cd}$ and $\mathrm{Pb}$ are mainly in the form of volatile chlorides and oxides in the MSWI fly ash [31-33], but these were quickly removed. Therefore, it was not easy to react with minerals to form stable compounds at high temperature.

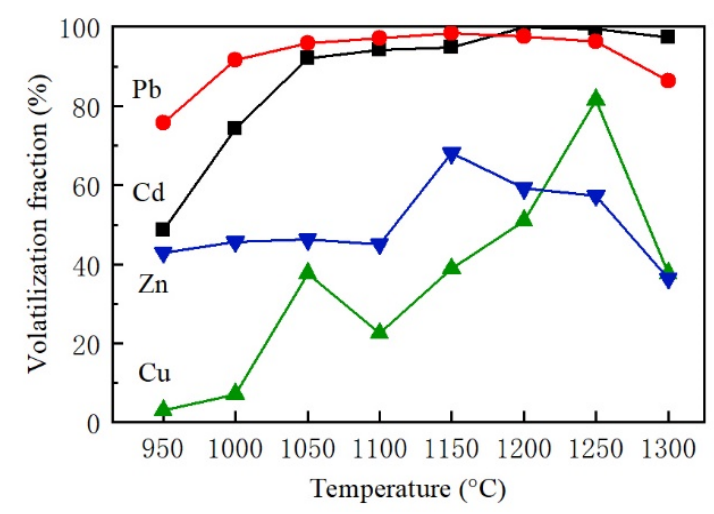

Figure 4. Effect of temperature on the volatilization of $\mathrm{Cd}, \mathrm{Pb}, \mathrm{Zn}$, and $\mathrm{Cu}$.

The volatilization of $\mathrm{Zn}$ did not significantly change from $950{ }^{\circ} \mathrm{C}$ to $1100{ }^{\circ} \mathrm{C}$ and it stabilized at $43.0-45.1 \%$. There was an increase in this volatilization as temperature increased and, when the temperature reached $1150{ }^{\circ} \mathrm{C}$, it decreased. As temperature increased, $\mathrm{Zn}$ could react with $\mathrm{SiO}_{2}$ and $\mathrm{Al}_{2} \mathrm{O}_{3}$ and form stable metallic species, such as $\mathrm{Zn}_{2} \mathrm{SiO}_{4} / \mathrm{ZnAl}_{2} \mathrm{O}_{4}$ [16,34], which can also promote the immobilization of $\mathrm{Zn}$. In addition, the production of liquid slag can also promote reactions that can further inhibit Zn volatilization.

The volatilization of $\mathrm{Cu}$ increased with the increase of temperature. There was an increase at $1050{ }^{\circ} \mathrm{C}$, which may have been an experimental error. After reaching a maximum of $81.5 \%$ at $1250{ }^{\circ} \mathrm{C}$, it began to decline significantly. At a high temperature, under an oxidizing atmosphere, $\mathrm{Cu}$ can transform non-volatile $\mathrm{CuO}$ and $\mathrm{Cu}_{2} \mathrm{O}$ [35]. When the temperature is higher than the FT, the liquid slag promotes the immobilization of $\mathrm{Cu}$.

When the temperature is below $1200^{\circ} \mathrm{C}$, the volatilization fraction of heavy metals was $\mathrm{Pb}>\mathrm{Cd}>\mathrm{Zn}>\mathrm{Cu}$. $\mathrm{Pb}, \mathrm{Cd}$, and $\mathrm{Cu}$ had the same variation trend as the temperature increased, the volatilization increased first, and then decreased after reaching the FT. When compared with $\mathrm{Pb}, \mathrm{Cd}$, and $\mathrm{Cu}, \mathrm{Zn}$ first began to show a downward trend. When the temperatures were higher than the FT, the volatilization of all four heavy metals decreased, which may be due to the following two reasons: first, heavy metals in the fly ash were more likely to enter a vitreous slag matrix as the temperature increased, so the volatilization reduced. Second, the liquid slag filled in the gaps of fly ash particles and led to densification, which increased the volatilization resistance of the heavy metals. 


\subsection{Leaching Behavior of Heavy Metals}

Figure 5 shows the leaching concentrations of $\mathrm{Cd}, \mathrm{Pb}, \mathrm{Zn}$, and $\mathrm{Cu}$ from the fly ash and heated slag. In the raw fly ash, the concentrations of $\mathrm{Cd}(1.51 \mathrm{mg} / \mathrm{L})$ and $\mathrm{Pb}$ $(1.49 \mathrm{mg} / \mathrm{L})$ exceeded the limits of the Chinese standard GB16889-2008 (Cd: $0.15 \mathrm{mg} / \mathrm{L}$; $\mathrm{Pb}: 0.25 \mathrm{mg} / \mathrm{L}$ ) [36]. Therefore, fly ash cannot be disposed in a landfill without further treatment. When the heating temperatures were below $1200^{\circ} \mathrm{C}$, the leaching concentration of $\mathrm{Cd}, \mathrm{Pb}, \mathrm{Zn}$, and $\mathrm{Cu}$ varied greatly as the temperature increased. When the temperature increased above $1200{ }^{\circ} \mathrm{C}$, the leaching concentration of $\mathrm{Cd}, \mathrm{Pb}, \mathrm{Zn}$, and $\mathrm{Cu}$ decreased significantly. This indicates that the formation of liquid slag at a high temperature improved the stability of the heavy metals in the products and reduced the migration of $\mathrm{Cd}, \mathrm{Pb}, \mathrm{Zn}$, and $\mathrm{Cu}$. This means that the stability of heavy metals in the glass slag was greater than that in the sintering slag.
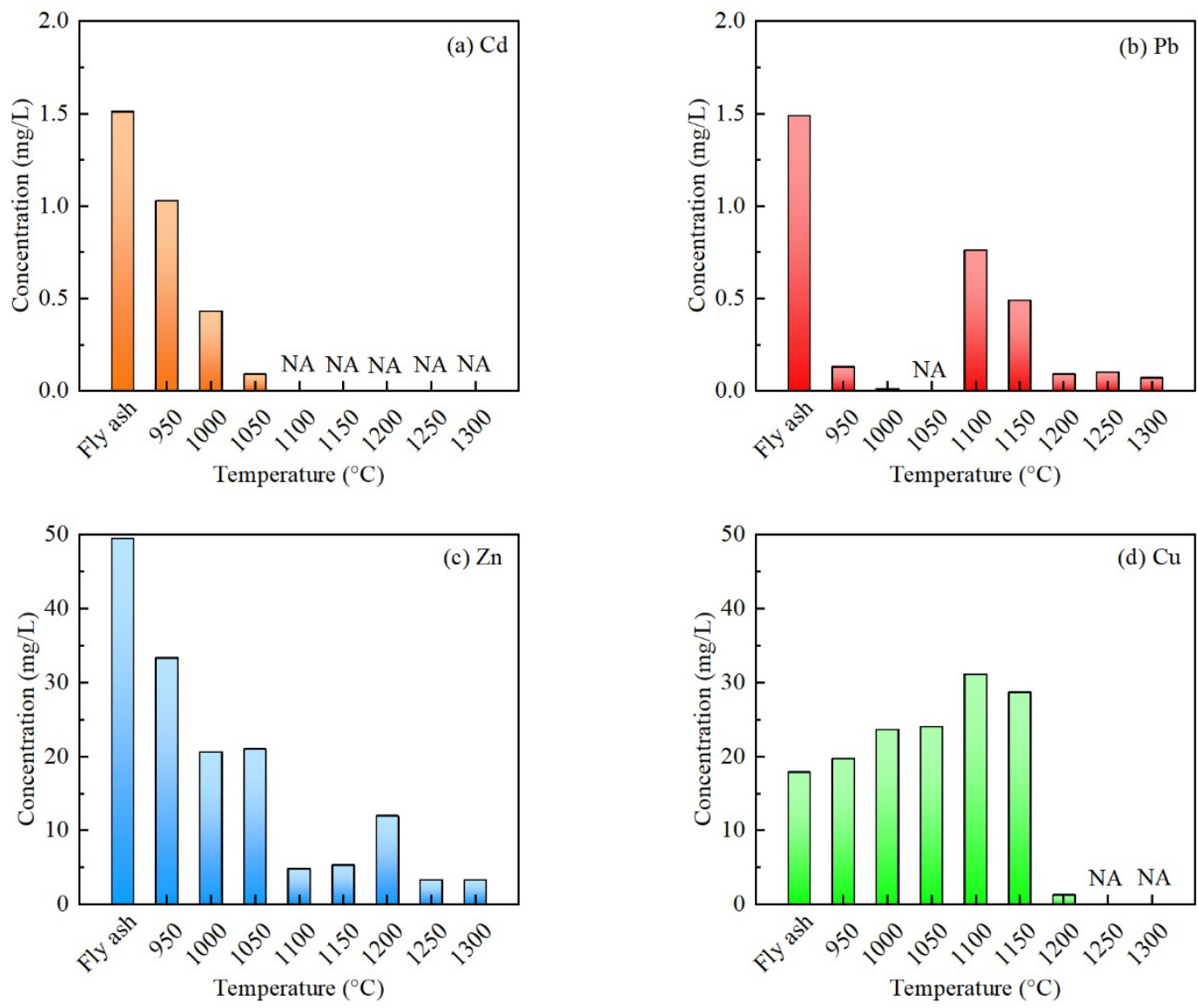

Figure 5. Leaching concentrations of $\mathrm{Cd}, \mathrm{Pb}, \mathrm{Zn}$, and $\mathrm{Cu}$ from the fly ash and heated slag.

\section{Conclusions}

Fly ash contains a large number of particles that can form a glass matrix and a small amount of chloride particles. As the temperature increased, oxide minerals transformed into gehlenite. When the temperature increased to $1300^{\circ} \mathrm{C}$, which was $89^{\circ} \mathrm{C}$ higher than the FT, all of the crystals transformed into molten slag, and they formed a glassy slag after quenching. When the heating temperatures were higher than the FT, the volatilization of $\mathrm{Pb}, \mathrm{Cd}, \mathrm{Zn}$, and $\mathrm{Cu}$ decreased, which may have been influenced by the formation of liquid slag. In addition, the formation of liquid slag at a high temperature improved the stability of the heavy metals in the heated slag. After melting solidification, the slag can be disposed of in a landfill according to the Chinese standard GB16889-2008 [36]. 
Author Contributions: Conceptualization, J.G. and X.H.; methodology, T.W.; validation, J.Z.; formal analysis, J.G.; investigation, J.G.; resources, X.H.; data curation, J.Z.; writing-original draft preparation, J.G. and T.W.; supervision, J.Z. and X.H.; Writing-Review \& Editing, C.D. All authors have read and agreed to the published version of the manuscript.

Funding: This research was funded by the National Basic Research Program of China (Grant 2015CB251501) and the Fundamental Research Funds for the Central Universities (2018ZD08 and 2019MS032).

Institutional Review Board Statement: Not applicable.

Informed Consent Statement: Not applicable.

Data Availability Statement: The data presented in this study are available on request from the corresponding author.

Conflicts of Interest: The authors declare no conflict of interest.

\section{References}

1. Ministry of Ecology and Environment of the People's Republic of China. Hazardous Waste List. 2016. Available online: http://www.mee.gov.cn/gkml/hbb/bl/201606/t20160621_354852.htm (accessed on 20 December 2020).

2. Quina, M.J.; Bontempi, E.; Bogush, A.; Schlumberger, S.; Weibel, G.; Braga, R.; Funari, V.; Hyks, J.; Rasmussen, E.; Lederer, J. Technologies for the management of MSW incineration ashes from gas cleaning: New perspectives on recovery of secondary raw materials and circular economy. Sci. Total Environ. 2018, 635, 526-542. [CrossRef] [PubMed]

3. Lam, C.H.K.; Ip, A.W.M.; Barford, J.P.; McKay, G. Use of Incineration MSW Ash: A Review. Sustainability 2010, 2, $1943-1968$. [CrossRef]

4. Yu, J.; Sun, L.; Ma, C.; Qiao, Y.; Xiang, J.; Hu, S.; Yao, H. Mechanism on heavy metals vaporization from municipal solid waste fly ash by $\mathrm{MgCl} 2 \cdot 6 \mathrm{H} 2 \mathrm{O}$. Waste Manag. 2016, 49, 124-130. [CrossRef] [PubMed]

5. Li, R.D.; Nie, Y.F.; Wang, L.; Li, A.M.; Chi, Y.; Cen, K.F. Migration characteristics experiment of heavy metal in the vitrification course of fly ash from municipal solid waste incineration. China Environ. Sci. 2004, 24, 480-483.

6. Katou, K.; Asou, T.; Kurauchi, Y.; Sameshima, R. Melting municipal solid waste incineration residue by plasma melting furnace with a graphite electrode. Thin Solid Film. 2001, 386, 183-188. [CrossRef]

7. Abanades, S.; Flamant, G.; Gagnepain, B.; Gauthier, D. Fate of heavy metals during municipal solid waste incineration. Waste Manag. Res. 2002, 20, 55-68. [CrossRef]

8. Evans, J.; Williams, P.T. Heavy Metal Adsorption onto Fly ash in Waste Incineration Flue Gases. Process Saf. Environ. Prot. 2000, 78, 40-46. [CrossRef]

9. Yu, J.; Qiao, Y.; Jin, L.; Ma, C.; Paterson, N.; Sun, L. Removal of toxic and alkali/alkaline earth metals during co-thermal treatment of two types of MSWI fly ashes in China. Waste Manag. 2015, 46, 287-297. [CrossRef]

10. Tian, S.L. Thermal-Separation Process and Evaporation Mechanism of Heavy Metal from MSWI Fly Ash; Harbin Institute of Technology: Harbin, China, 2007.

11. Ma, W.; Fang, Y.; Chen, D.; Chen, G.; Zhou, Z. Volatilization and leaching behavior of heavy metals in MSW incineration fly ash in a DC arc plasma furnace. Fuel 2017, 210, 145-153. [CrossRef]

12. Wu, S.; Xu, Y.; Sun, J.; Cao, Z.; Zhou, J.; Pan, Y.; Qian, G. Inhibiting evaporation of heavy metal by controlling its chemical speciation in MSWI fly ash. Fuel 2015, 158, 764-769. [CrossRef]

13. Kirk, D.W.; Chan, C.C.Y.; Marsh, H. Chromium behavior during thermal treatment of MSW fly ash. J. Hazard. Mater. 2002, 90, 39-49. [CrossRef]

14. Chan, C.C.Y.; Kirk, D.W.; Marsh, H. The behaviour of Al in MSW incinerator fly ash during thermal treatment. J. Hazard. Mater 2000, 76, 103-111. [CrossRef]

15. Tian, S.; Li, J.; Liu, F.; Guan, J.; Dong, L.; Wang, Q. Behavior of Heavy Metals in the Vitrification of MSWI Fly Ash with a Pilot-scale Diesel Oil Furnace. Procedia Environ. Sci. 2012, 16, 214-221. [CrossRef]

16. Jakob, A.; Stucki, S.; Struis, R.P.W.J. Complete heavy metal removal from fly ash by heat treatment: Influences of chlorides on evaporation rates. Environ. Sci. Technol. 1996, 30, 3275-3283. [CrossRef]

17. Nowak, B.; Rocha, S.F.; Aschenbrenner, P.; Rechberger, H.; Winter, F. Heavy metal removal from MSW fly ash by means of chlorination and thermal treatment: Influence of the chloride type. Chem. Eng. J. 2012, 179, 178-185. [CrossRef]

18. Yen, C.-P.; Zhou, S.-Y.; Shen, Y.-H. The Recovery of Ca and Zn from the Municipal Solid Waste Incinerator Fly Ash. Sustainability 2020, 12, 9086. [CrossRef]

19. Hu, H.; Liu, H.; Shen, W.; Luo, G.; Li, A.; Lu, Z.; Yao, H. Comparison of CaO's effect on the fate of heavy metals during thermal treatment of two typical types of MSWI fly ashes in China. Chemosphere 2013, 93, 590-596. [CrossRef]

20. General Administration of Quality Supervision, Inspection and Quarantine of the People's Republic of China. Determination of Fusibility of Coal Ash; Standards Press of China: Beijing, China, 2008. 
21. Ministry of Ecology and Environment of the People's Republic of China. Soil Quality—Determination of Lead, Cadmium—Graphite Furnace Atomic Absorption Spectrophotometry; China Environmental Press: Beijing, China, 1997.

22. Ministry of Ecology and Environment of the People's Republic of China. Solid Waste-Extraction Procedure for Leaching ToxicityAcetic Acid Buffer Solution Method; China Environmental Press: Beijing, China, 2007.

23. Ministry of Ecology and Environment of the People's Republic of China. Solid Waste-Determination of Lead, Cadmium-Graphite Furnace Atomic Absorption Spectrophotometry; China Environmental Science Press: Beijing, China, 2016.

24. Li, H.; Wang, H.; Geng, H.Y.; Fang, J.H.; Bai, L.C. A study on physical and chemical characteristics of fly ash from municipal solid waste incinerator. Chin. J. Environ. Eng. 2007, 1, 137-140.

25. Wang, K.-S.; Sun, C.-J.; Yeh, C.-C. The thermotreatment of MSW incinerator fly ash for use as an aggregate: A study of the characteristics of size-fractioning. Resour. Conserv. Recycl. 2002, 35, 177-190. [CrossRef]

26. Guo, Y.W.; Wang, W.; Gao, X.B.; Qiao, W. Microstructure chatacteristic and X-ray energy dispersive microanalysis of MSW incineration fly ash. J. Fuel Chem. Technol. 2005, 33, 703-707.

27. Zheng, B.; Luo, Y.; Liao, H.; Zhang, C. Investigation of the crystallinity of suspension plasma sprayed hydroxyapatite coatings. J. Eur. Ceram. Soc. 2017, 37, 5017-5021. [CrossRef]

28. Xie, K.; Hu, H.; Xu, S.; Chen, T.; Huang, Y.; Yang, Y.; Yang, F.; Yao, H. Fate of heavy metals during molten salts thermal treatment of municipal solid waste incineration fly ashes. Waste Manag. 2020, 103, 334-341. [CrossRef] [PubMed]

29. Wang, S.-J.; He, P.-J.; Xia, Y.; Lu, W.-T.; Shao, L.-M.; Zhang, H. Role of sodium chloride and mineral matrixes in the chlorination and volatilization of lead during waste thermal treatment. Fuel Process. Technol. 2016, 143, 130-139. [CrossRef]

30. Wang, S.J.; He, P.J.; Lu, W.T.; Shao, L.M.; Zhang, H. Comparison of Pb, Cd, Zn, and Cu chlorination during pyrolysis and incineration. Fuel 2017, 194, 257-265. [CrossRef]

31. Cao, L. Study on the Partitioning and Speciation of Elements from Municipal Solid Waste Incineration and Their Environmental Effects by Synchrotron Techniques; Chinese Academy of Sciences: Shanghai, China, 2015.

32. Pinzani, M.C.C.; Somogyi, A.; Simionovici, A.S.; Ansell, S.; Steenari, B.; Lindqvist, O. Direct Determination of Cadmium Speciation in Municipal Solid Waste Fly Ashes by Synchrotron Radiation Induced $\mu$-X-ray Fluorescence and $\mu$-X-ray Absorption Spectroscopy. Environ. Sci. Technol. 2002, 36, 3165-3169. [PubMed]

33. Pinzani, M.C.C.; Ansell, S.; Somogyi, A.; Steenari, B.M.; Lindqvist, O. Microextended X-ray Absorption Fine Structure Studies of Cadmium Speciation within Single Municipal Solid Waste Fly Ash Particles. Anal. Chem. 2004, 76, 1596-1602. [CrossRef]

34. Yu, J.; Sun, L.; Xiang, J.; Hu, S.; Su, S. Kinetic vaporization of heavy metals during fluidized bed thermal treatment of municipal solid waste. Waste Manag. 2013, 33, 340-346. [CrossRef]

35. Wang, X.T.; Jin, B.S.; Zhong, Z.P.; Dang, X.J. Influence of atmospheres on behavior of heavy metals during melting process of fly ashes from municipal solid waste incinerator. Proc. CSEE 2006, 26, 47-52.

36. Ministry of Environmental Protection of the People's Republic of China. Standard for Pollution Control on the Landfill Site of Municipal Solid Waste; China Environmental Science Press: Beijing, China, 2008. 